\title{
Determinants of Net Interest Margin on Conventional Banking: Evidence in Indonesia Stock Exchange
}

\author{
Henny Setyo Lestari ${ }^{*}$, Helda Chintia ${ }^{2}$, Ilham Cahyo Akbar ${ }^{3}$ \\ ${ }^{123}$ Department of Management, Faculty of Economics and Business, Trisakti University, \\ Indonesia. \\ *Corresponding Author: henny.sudradjad@gmail.com
}

\begin{abstract}
Net Interest Margin (NIM) is an important indicator in assessing the sustainability and health of the banking system. A bank that has a high NIM means that the bank has a greater opportunity to generate profits, power to resist the financial crisis, and provide welfare for parties who have an interest in the bank. This study aims to determine the factors that influence NIM. The sample used in this study is the banking industry listed on the Indonesia Stock Exchange (BEI) from 2015 to 2019. In this study the independent variables used are bank size, lending scale, credit risk, equity capital, loan to deposit ratio, management efficiency and inflation rate. The dependent variable in this study is NIM. The number of samples used was 37 conventional banks which were taken using purposive sampling method. By using multiple regression analysis with the General Least Square (GLS) approach method. The results of this study indicate that the bank size, credit risk, equity capital, loan to deposit ratio, management efficiency and inflation rate have an effect on NIM, while the lending scale has no effect on NIM. The results of this study are expected to be used by future researchers, bank managers, and investors in determining the factors that can affect the NIM at the Bank.
\end{abstract}

Keywords $\quad$ : Bank size; Credit risk; Equity capital; Inflation; Loan to deposit ratio; Management efficiency; Net interest income

JEL Classification : G21

\section{INTRODUCTION}

The financial sector is one of the most important factors as well as the backbone of a country's economy. It serves as an intermediary for achieving sustainable economic growth. Banks have an important role in the economy which is the key to investment and economic growth (Menicucci and Paolucci, 2016). This institution has a main function, 
namely by mobilizing its resources, especially in the form of deposits, channeling funds from customers who have excess funds to those who need funds. This makes investment opportunities productive (Ram and Mesfin, 2019). In another case, this shows that banks are an important source of funding related to the economy of a country (Diko, 2019).

The health of banking from year to year can be seen from the increased level of efficiency and profitability, this can be seen from the level of capital that has also increased (Diko, 2019). The current global financial crisis has shown that banks are judged by their health, whether they can mitigate or strengthen the impact of financial shocks on the real economy. To maintain the level of financial stability and economic growth, the banking sector must have adequate capital, this can be realized with a good level of profitability (Angori et. al., 2019). A good level of bank profitability is very important in assessing the health of the banking sector, with a high level of profitability, this will reflect the health of the bank (Suu et al., 2020)

One measure of the level of profitability in the banking sector can be measured by using the net interest margin. The net interest margin is used to calculate the difference between the interest income received from loans and the interest expense paid to customers who deposit their funds in the bank. The net interest margin level and dynamics will indicate the efficiency of financial intermendiation (Plakalovic and Alihodzic, 2015). Net interest margin according to Pham et. al., (2018), is a method for measuring effectiveness and profitability as a core indicator because the net interest margin contributes to bank income around $70 \%$ to $80 \%$ of bank revenue, as a consequence the higher this ratio, the bank's income will increase.

Several factors influence the net interest margin, based on research conducted by Pham et. al., (2019) including bank size, lending scale, credit risk, equity capital, loan to deposit ratio, management efficiency and inflation rate. Bank size describes how big the scale of the size of a bank is, this aspect of determining the bank size can be seen from the aspects of finance, resources and other assets (Maji and Hazarika, 2018). Lending scale interprets stability of the banking sector and become a source of assessment in the main funding reference for banks (Suu et al., 2020). According to research conducted by yg Ram et. al., (2019) the lending scale will determine how much income a bank can afford, this is measured through interest income to total income ratio and the bank's ability to generate income from its loan services.

Credit risk is used as an indicator to measure the potential losses incurred by valuable assets with the possibility of a decrease in the creditworthiness of the debtor or its inability to meet contractual obligations Manab et al., (2015). Credit risk is defined as the general reserve used for credit losses against gross loans. Equity Capital is used to assess capital adequacy and assess the general health of the bank in this case to represent how good the bank is in terms of capital (Menicucci et. al., 2016). Equity capital can be calculated using the ratio of equity to total assets. Equity capital should be driven by multiple aggregated welfare objectives that take into account that higher capital requirements benefit the economy by reducing the likelihood of a banking crisis while imposing economic costs in terms of lower potential economic returns (Junge and Kugler, 2018).

Research carried out by Islam and Nishiyama (2016) states that the loan to deposit ratio is used in assessing the strength of funding and is used as an indicator to see how 
many loans have been funded through deposits and other funding sources that have a deterministic significantly to the net interest margin, In the results of his research the loan to deposit ratio shows an increase in net interest margin, where the higher the loan to deposit ratio, the net interest margin will increase. Management efficiency is stated in research conducted by Jima (2017) that has an important role in the banking sector, especially in determining the balance of profit earning assets and net profit in generating sources of income, this also plays an important role in allocating scarce resources in a profitable sector, with This good level of efficiency management will result in better income and also be competitive in the market, in contrast to banks that have a bad level of efficiency management, they tend to need effort to survive and struggle in their business.

The inflation rate in this case will reflect a decrease in purchasing power per unit from a loss of real value in the medium of exchange and a unit of account in the economy (Addai et. al., 2016). Inflation rate can be measured by measuring changes in the market price level of consumer goods as well services purchased by households. Inflation becomes an external variable to account for economic uncertainty. This happens because relationship between inflation and net interest margin can produce mixed results. The results can be positive or negative depending on the anticipation by the bank management when determining the loan interest rate (Boateng, 2018)

\section{HYPOTHESES DEVELOPMENT}

Research conducted by Pham et. al., (2019) stated that bank size has a statistically insignificant effect on net interest margin. Another study conducted by Agoraki and Kouretas (2019) found that bank size has a negative effect on net interest margin. Phamhoang and Vo (2017) found that there was a positive influence between bank sizes with a net interest margin. Ram et. al., (2019) stated in their research that bank size has a positive and significant effect on net interest margin. Based on the explanation above, the following hypothesis can be formulated:

H1: Bank Size has positive influence on Net Interest Margin.

Research conducted by Pham, et. al., (2019) states that there is a positive influence between lending scale and net interest margin. This is supported by the results of research conducted by Pham et. al., (2018) that there is a positive influence between lending scale and net interest margin. Another result of research conducted by Phamhoang et. al., (2017) stated that there is a negative influence between lending scale and net interest margin. Based on the explanation above, the following hypothesis can be formulated:

H2: Lending Scale has positive influence on Net Interest Margin.

Research conducted by Pham, et. al., (2019) states that credit risk has an insignificant effect statistically against the net interest margin. Research conducted by Suu et al., (2020) found that there is a positive influence between credit risk and net interest margin. This is supported by Plakalovic et. al., (2015) finding that there is a positive influence between credit risk and net interest margin. Based on the explanation above, the following hypothesis can be formulated:

H3: Credit Risk has positive influence on Net Interest Margin. 
Research conducted by Pham, et. al., (2019) found that there is a positive influence between equity capital and net interest margin. This is supported by Pham et al., (2018) who found that there is a positive influence between equity capital and net interest margin. Phamhoang et. al., (2017) found that there is a negative influence between equity capital and net interest margin. Based on the explanation above, the following hypothesis can be formulated:

H4: Equity Capital has positive influence on Net Interest Margin.

Research conducted by Pham, et. al., (2019) found that there is no statistically significant effect between loan to deposit ratio and net interest margin. Research conducted by Chowdhury et al., (2016) found that there is a positive influence between the loan to deposit ratio and the net interest margin. This is supported by Islam and Nishiyama (2015) who found that there was a positive influence between the loan to deposit ratio and the net interest margin. Based on the explanation above, the following hypothesis can be formulated:

H5: Loan to Deposit Ratio has positive influence on Net Interest Margin.

Research conducted by Pham, et. al., (2019) found that there was a negative influence between management efficiency and net interest margin. This is supported by Phamhoang et. al., (2017) finding that there is a negative influence between management efficiency and Net Interest Margin. Khalil and Farooq, (2019) found different results that there was a positif influence between the management efficiency and the net interest margin. Based on the explanation above, the following hypothesis can be formulated:

H6: Management Efficiency has negative influence on Net Interest Margin.

Research conducted by Pham, et. al., (2019) found that there was a positive influence between inflation rate and net interest margin. This is also supported by Agoraki et. al., (2019) finding that there is a positive influence between inflation rate and net interest margin. Barik and Raje (2019) also found that there was a positive influence between inflation rate and net interest margin. Ali Bhati et al., (2018) found different results that there was a negative influence between the inflation rate and the net interest margin. Based on the explanation above, the following hypothesis can be formulated:

H7: Inflation Rate has positive influence on Net Interest Margin.

\section{METHOD, DATA AND ANALYSIS}

In this study, the data used is secondary data. The data is obtained from the annual financial reports of conventional banks listed on the Indonesia Stock Exchange (IDX) from 2015 to 2019, the total conventional banks are 47 banks that have been listed on IDX. After banks with incomplete financial information, we use 37 for 5 years.

The data analysis method used in this study is multiple panel regression. Multiple Panel Regression is a regression analysis method that combines cross section and time series data. Multiple Panel Regression is used to measure the influence of independent variables, namely bank size, lending scale, credit risk, equity capital, loan to deposit ratio, 
management efficiency, and inflation rate depending on the variable, namely net interest margin. With the regression equation model as follows:

$\mathrm{NIM}=\beta 0+\beta 1 \mathrm{SiZE}+\beta 2 \mathrm{LAR}+\beta 3 \mathrm{CR}+\beta 4 \mathrm{CAP}+\beta 5 \mathrm{LDR}+\beta 6 \mathrm{CTI}+\beta 7 \mathrm{INFL}+\mathrm{u}_{\mathrm{it}}$

Where:

$\begin{array}{ll}\text { NIM } & \text { : Net Interest Margin } \\ \text { SiZE } & \text { : Bank Size } \\ \text { LAR } & \text { : Lending Scale } \\ \text { CR } & : \text { Credit Risk } \\ \text { CAP } & : \text { Equity Capital } \\ \text { LDR } & : \text { Loan to Deposit Ratio } \\ \text { CTI } & : \text { Management Efficiency } \\ \text { INFL } & : \text { Inflation Rate }\end{array}$

Table 1. Research variables measurements

\begin{tabular}{llr}
\hline \multicolumn{2}{c}{ Variable } & \multicolumn{1}{c}{ Measurements } \\
\hline $\begin{array}{l}\text { Independent Variables } \\
\text { Bank Size }\end{array}$ & Logarithm of Total Asset & \\
Lending Scale & Loan Outstanding / Total Asset & SIZE \\
Credit Risk & Credit Provision / Total Loan Outstanding & LAR \\
Equity Capital & Equity / Total Asset & CR \\
Loan to Deposit Ratio & Total Loan / Total Deposit & CAP \\
Management Efficiency & Operating Cost / Total Income & LDR \\
Inflation Rate & Annual Rate of Inflation & CTI \\
Dependent Variables & & INFL \\
Net Interest Margin & (Interest Income - Interest Expense) / Total Earning & NIM \\
& Asset & \\
\hline
\end{tabular}

Table 2. Descriptive statistics

\begin{tabular}{cccccc}
\hline Variables & Obs. & Mean & Maximum & Minimum & Std. Dev \\
\hline NIM & 185 & 0.053314 & 0.193000 & 0.003900 & 0.025049 \\
SIZE & 185 & 31.10050 & 34.88715 & 26.92703 & 1.984421
\end{tabular}




\begin{tabular}{cccccc}
\hline Variables & Obs. & Mean & Maximum & Minimum & Std. Dev \\
\hline LAR & 185 & 0.0647796 & 5.937253 & 0.061269 & 0.404026 \\
CR & 185 & 0.026110 & 0.140612 & 0.000570 & 0.022037 \\
CAP & 185 & 0.181088 & 0.974824 & 0.008746 & 0.123302 \\
LDR & 185 & 0.968319 & 9.274651 & 0.073524 & 1.036757 \\
CTI & 185 & 9.147388 & 615.3569 & -47.10354 & 47.61222 \\
INFL & 185 & 0.039900 & 0.063800 & 0.030300 & 1.324531 \\
\hline
\end{tabular}

Description:

1. SIZE (Bank Size) the average SIZE value is 31,10050 with a standard deviation of 1.984421 , a minimum value of 26.92703 , and a maximum value of 34.88715 .

2. LAR (Lending Scale) an average LAR value of 0.0647796 with a standard deviation of 0.404026 , a minimum value of 0.061269 , and a maximum value of 5.937253 .

3. CR (Credit Risk) average CR value of 0.026110 with a standard deviation of 0.022037 , a minimum value of 0.000570 , and a maximum value of 0.140612 .

4. CAP (Equity Capital) the average CAP value is 0.181088 with a standard deviation of 0.123302 , the minimum value of 0.008746 , and the value of $\mathrm{m}$ aximum is 0.974824 .

5. LDR (Loan to Deposits Ratio) the average LDR value is 0.968319 with a standard deviation of 1.036757 , the minimum value is 0.073524 , and a maximum value of 9,274651 .

6. CTI (Management Efficiency) mean CTI value of 9,147388 with a standard deviation of 1.036757 , a minimum value of -47.1035 , and a maximum value of 615.3569 .

7. INFL (Inflation Rate) the average INFL value is 0.039900 with a standard deviation of 1.324531 , a minimum value of 0.030300 in 2019, and a maximum value of 0.063800 in 2015.

\section{RESULTS}

Table 2 shows that conventional banks in Indonesia are still dominated by banks that have a low level of net interest margin. It can be seen based on the average value of the dependent variable NIM criteria compared to the maximum value of each variable. 
The average NIM value is 0.05 percent and the maximum value is 0.19 percent. While the analysis measured using SIZE which has an average value in conventional banks of 31.1 percent, it can be ignored that SIZE does not show a significant value compared to the maximum value.

Table 3. Best Model Selection

\begin{tabular}{ll}
\hline Model Test & Best Model \\
\hline Uji Chow & Fixed Effect \\
Uji Hausman & Random Effect \\
\hline
\end{tabular}

This study found that the best model used in this study is the random effect model. The estimation of the random effect model works as a General Least Square (GLS) until the results of the classical test assumptions are rejected. The results of the analysis of the influence of bank size, lending scale, credit risk, equity capital, loan to deposit ratio, management efficiency and inflation rate on net interest margin using the random effect can be seen in Table 3 .

Based on the results of the $t$ test using NIM as the dependent variable and using data of conventional banks listed on the Indonesian Stock Exchange in 2015 to 2019 are as Table 4.

Table 4. T-test Results.

Dependent Variables: Net Interest Margin

\begin{tabular}{ccccc}
\hline Independent Variables & Coef. & Prob. & Hypotheses & Conclusion \\
\hline C & 0.475017 & 0.0000 & & \\
SIZE & -0.013392 & 0.0000 & Ha Accepted & Significant \\
LAR & -0.000735 & 0.2088 & Ha Rejected & Not Effected \\
CR & -0.026226 & 0.0012 & Ha Accepted & Significant \\
CAP & -0.011592 & 0.0020 & Ha Accepted & Significant \\
LDR & 0.000994 & 0.0055 & Ha Accepted & Significant \\
CTI & $1.92 \mathrm{E}-05$ & 0.0074 & Ha Accepted & Significant \\
INFL & -0.077238 & 0.0000 & Ha Accepted & Significant \\
\hline
\end{tabular}


Based on the results of the research obtained size (SIZE) has a significant negative effect on net interest margin, this shows that any increase in size (SIZE) will cause a decrease in net interest margin. Lending scale (LAR) has no effect on the net interest margin, this shows that any increase or decrease in the lending scale (LAR) does not will cause an increase or decrease in the net interest margin. Credit risk (CR) has a significant negative effect on net interest margin, this shows that any increase in credit risk (CR) will cause a decrease in net interest margin.

Equity Capital (CAP) has a significant negative effect on net interest margin, this shows that any increase in equity capital (CAP) will cause a decrease in net interest margin. Loan to deposit ratio (LDR) has a significant positive effect on net interest margin, this shows that each increase in loan to deposit ratio (LDR) will cause an increase in net interest margin. Management efficiency (CTI) has a significant positive effect on net interest margin, this shows that any increase in management efficiency (CTI) will cause an increase in the net interest margin. Inflation rate (INFL) has a significant negative effect on the net interest margin, this shows that any increase in the inflation rate (INFL) will cause a decrease in the net interest margin

\section{DISCUSSION}

\section{Bank Size}

The results of this study indicate that bank size has a significant negative effect on net interest margin (NIM). This research is in line with the results of previous research conducted by Agoraki and Kouretas (2019) which states that bank size has a negative effect on net interest margin. Mazi and Hazarika (2018) states that the size of a bank describes how big the scale of a bank is, this aspect of determining the size of a bank can be seen from the aspects of finance, resources and other assets. The higher the size of the bank, the higher the assets of the bank. High assets will be accompanied by high liabilities and equity as well. Pham et. Al. (2019) states that NIM is used to calculate the difference between interest income received from loans and interest expenses paid to customers who deposit their funds in the bank. The higher the size of the bank, the greater the interest expense on deposits that must be paid by banks to customers, so that the net interest income on the difference between loan interest income minus deposit interest will be lower. This causes the higher the size of the bank, the lower the net interest margin. Phamhoang et. al., (2017) which states different result that there is a positive influence between bank size and net interest margin. The higher the bank size, the higher the net interest margin. The results of research conducted by Ram et al., (2019) state that bank size has a positive influence on net interest margin. This means that the higher the assets of a bank, the higher the level of asset productivity of a bank and will cause the bank's net interest margin to increase.

\section{Lending Scale}

The hypothesis in this study states that the results of research conducted by Pham, et. al., (2019) have a positive influence between the lending scale on the net interest margin. This is in line with the research results of Pham et. al., (2018) that there is a positive influence between the lending scale and the net interest margin. The theory states by Ram et. al., (2019) the lending scale determine how much income a bank can afford, this is measured through interest income to total income ratio and the bank's ability to generate income from its loan services. So the higher the lending scale on the bank, the 
higher the interest income obtained from loans so that it can affect the amount of net interest margin at the bank which will be even higher. Lending scale can be calculated by dividing total outstanding loans by total assets (Pham, et. al., 2019). A positive sign on the lending scale can be an indication that when the lending scale increases, this will increase the net interest margin. Phamhoang et. al., (2017) stated that there is a negative influence between the lending scale and the net interest margin. The results of this study indicate that an increase in the lending scale will have an impact on decreasing net interest margins.

\section{Credit Risk}

Based on the two hypotheses of this study, it indicates that credit risk has a positive effect on net interest margin. Suu et al., (2020) found that there is a positive influence between credit risk and interest margin. This statement is supported by Plakalovic et. al., (2015) found that there was a positive influence between credit risk and interest margin. It means that higher level of credit risk will cause an increase of net interest margin. Research conducted by Manab et. al., (2015) states that credit risk is used as an indicator in calculating potential losses from the value of assets owned by a bank that is lent to a debtor in fulfilling its obligations. Every increase in credit risk stems from the high amount of credit extended. With a high risk, it will cause the level of profits to increase. So that the net interest margin will increase. Another hypothesis from this study found that credit risk does not have a significant effect on net interest margin (Pham, et. al., 2019). This means that an increase or decrease in credit risk does not have any effect on the net interest margin.

\section{Equity Capital}

Two hypotheses of this study indicate that equity capital has a positive effect on net interest margin. Pham et. al., (2019) stated that there is a positive influence between equity capital and net interest margin. The higher the equity capital, the higher the net interest margin. This statement is supported by Pham et al., (2018) who found that there was a positive influence between equity capital and net interest margin. Menicucci et. al., (2016) states that equity capital is used to assess capital adequacy and assess the general health of the bank in this case to represent how good the bank is in terms of capital. So, higher the capital owned by the bank will make the bank more stable in running its business. High bank capital can also give a bank the strength to survive an economic crisis. The increase in capital in banks will also increase the net interest margin. Because with an increase in capital, banks can get additional investments that can be allocated into productive assets so that they can increase bank profits. Phamhoang et. al., (2017) states the different thing that there is a negative influence between equity capital and net interest margin. This indicates that an increase in equity capital will cause decrease in net interest margin.

\section{Loan to Deposit Ratio}

Pham et. al., (2019) stated that there is no statistically significant effect between loan to deposits ratio and net interest margin. The results of this study indicate that the increase or decrease in loan to deposits ratio has no effect on the increase or decrease in net interest margin. This result is different from the research conducted by Chowdhury et al., (2016) which states that there is a positive influence between the loan to deposit ratio and the net interest margin. An increase in the loan to deposit ratio will also increase the 
net interest margin. Islam et. al., (2015) states the same thing that there is a positive effect between loan to deposits ratio on net interest margin. Islam et. al., (2016) states that the loan deposit ratio is used to calculate the extent to which customer deposit funds are used by banks in loans to debtors. This will refer to the productivity of customer deposit funds that are lent to debtors, so that it will generate interest income for the bank which will cause the bank's net interest margin to increase. The positive effect on the loan to deposit ratio indicates that the high loan to deposit ratio causes the productivity of customer deposits to be converted into high loans. For this productivity, it will have the potential to increase the net interest margin from the loan interest yield.

\section{Management Efficiency}

Based on the three hypotheses of this study, it indicates that management efficiency has a negative effect on net interest margin. Pham et. al., (2019) found that there was a negative influence between management efficiency and net interest margin. This is because the decreasing level of management efficiency will increase the net interest margin. This statement is supported by Phamoang et. al., (2017) found that there is a negative influence between management efficiency and interest margin. This means that an increase in management efficiency will also increase control on bank operations so that the scope for granting management permits in providing credit will be narrowed. As a result, it will cause smaller loans to debtors, which will cause the net interest margin to decrease. Khalil et. al., (2019) found that there was a positive influence between management efficiency and interest margin. Jima (2017) states that good level of efficiency management will result in better income and also be competitive in the market, in contrast to banks that have a bad level of efficiency management, they tend to need effort to survive and struggle in their business. This indicates that an increase in management efficiency will lead to an increase in net interest margin.

\section{Inflation Rate}

The hypothesis put forward in this study states that the results of three previous studies found that there was a positive influence between inflation rate and net interest margin. Pham et. al., (2019) stated that there was a positive influence between inflation rate and net interest margin. The results of this study were supported by Agoraki et. al., (2019) which states that there is a positive influence between inflation rate and net interest margin. Other studies have similarly stated that the inflation rate has a positive effect on the inflation rate on the net interest margin. So an increase in inflation rate will cause the net interest margin to increase. This positive effect indicates that when there is an increase in inflation, banks can increase the loan interest rate as well so that it can cause the net interest margin to increase. Ali Bhati et al., (2018) found different results that there was a negative influence between the inflation rate and the net interest margin.

\section{CONCLUSION, LIMITATIONS AND SUGGESTIONS}

\section{Conclusion}

This research was conducted to determine the effect of bank size, lending scale, credit risk, equity capital, loan to deposit ratio, management efficiency and inflation rate on net interest margin. In this study, the sample used was 37 conventional banks listed on the Indonesian Stock Exchange in the 2015 to 2019 period. Based on the explanation previously described, the results show that bank size, credit risk, equity capital and inflation rate have a significant negative effect on net interest margins. Loan to deposit 
ratio and management efficiency have a significant positive effect on net interest margin. Another result of the lending scale shows that there is no influence on the net interest margin. This result is not in line with the results of the research we have done, but is in line with the results of research conducted by Suu et. al., (2020) which states that the loan ratio (lending scale) has no effect on net interest margin.

\section{Limitations}

This study uses a sample of conventional banks listed on the Indonesia Stock Exchange (IDX) during the period 2015 - 2019 and limited with a sample size of 37 conventional banking companies. There are 8 variables used in this study, including net interest margin, bank size, lending scale, credit risk, equity capital, bank size, loan to deposit ratio, management efficiency and inflation rate.

\section{Suggestions}

The results of the discussion conclude that the recommendation for this study is to conduct other studies using different variables to get maximum results or by adding other related variables that have an influence on net interest margin such as non-performing loans, this is appropriate with research that has been done by (Islam and Nishiyama, 2015).

\section{REFERENCES}

Addai, B., Gyimah, A. G., \& Lartey, S. (2016). The Determinants of Net Interest Margin In Indonesia's Commercial Banks. 7(November 2010), 73-80.

Agoraki, M. E. K., \& Kouretas, G. P. (2019). The determinants of net interest margin during transition. Review of Quantitative Finance and Accounting, 53(4), 1005-1029. https://doi.org/10.1007/s11156-018-0773-y

Ali Bhati, G., Bashir, Z., Abbas, Z., \& Hassan Mirza, H. (2018). Determinants of Net Interest Margin-A Study Based On Conventional Banks Of Pakistan. The Pakistan Journal of Social Issues, IX(1), 92-105.

Angori, G., Aristei, D., \& Gallo, M. (2019). Determinants of banks' net interest margin: Evidence from the Euro Area during the crisis and post-crisis period. Sustainability (Switzerland), 11(14). https:// doi.org/10.3390/su11143785

Barik, S. S., \& Raje, N. (2019). Net Interest Margins of Banks in India. Margin, 13(2), 192207. https://doi.org/10.1177/0973801018812545

Boateng, K. (2018). Determinants of Bank Profitability: A Comparative Study of Indian and Ghanaian Banks. 5(5), 643-654.

Chowdhury, A. N. M. M. H., Siddiqua, A., \& Chowdhury, A. S. M. M. H. (2016). Relationship between Liquidity Risk and Net Interest Margin of Conventional 
Banks in Bangladesh. Asian Business Review, 6(3), 175-178. https://doi.org/10.18034/abr.v6i3.43

Diko, A. (2019). Determinants of Net Interest Margins in Turkish Banking System: A Panel Data Analysis. April.

Islam, M. S., \& Nishiyama, S. I. (2016). The determinants of bank net interest margins: A panel evidence from South Asian countries. Research in International Business and Finance, 37(January), 501-514. https:// doi.org/10.1016/j.ribaf.2016.01.024

Jima, M. D. (2017). Determinants of Net Interest Margin in the Ethiopian Banking Industry Meshesha. Journal of Finance and Economics, 5(3), 96-104. https://doi.org/10.12691/jfe-5-3-2

Junge, G., \& Kugler, P. (2018). Optimal equity capital requirements for large Swiss banks. Swiss Journal of Economics and Statistics, 154(1). https://doi.org/10.1186/s41937-0180025-z

Khalil, A., \& Farooq, U. (2019). Determinants of Net Interest Margins in Emerging Markets: A Generalized Method of Moments Approach. Journal of Quantitative Methods, 3(1), 38-55. https://doi.org/10.29145/2019/jqm/030103

Maji, S. G., \& Hazarika, P. (2018). Managerial Finance. Managerial Finance. https://doi.org/10.4324/9780080938196

Manab, N. A., Theng, N. Y., \& Md-Rus, R. (2015). The Determinants of Credit Risk in Malaysia. Procedia - Social and Behavioral Sciences, 172(October), 301-308. https://doi.org/10.1016/j.sbspro.2015.01.368

Menicucci, E., \& Paolucci, G. (2016). The determinants of bank profitability: empirical evidence from European banking sector. In Journal of Financial Reporting and Accounting (Vol. 14, Issue 1). https:/ / doi.org/10.1108/jfra-05-2015-0060

Pham, A. H., Tran, C., \& Anh, L. H. (2018). Econometrics for financial applications. January 2018, 1081. https:// doi.org/10.1007/978-3-319-73150-6

Pham, A. H., Tran, C., \& Anh, L. H. (2019). Beyond traditional probabilistic methods in econometrics. Studies in Computational Intelligence, 809(January), 3-21. https://doi.org/10.1007/978-3-030-04200-4_1

Pham, H. A., \& Vo, T. K. L. (2017). Factors affecting net interest margin of joint-stock commercial banks in Vietnam. Journal of Asian Business and Economic Studies, 24(01), 92-103. https:// doi.org/10.24311/jsabes/2017.24.1.01

Plakalovic, N., \& Alihodzic, A. (2015). Determinants of the net interest margins in BH 
banks. Industrija, 43(1), 133-153. https://doi.org/10.5937/industrija43-7544

Ram, V., \& Mesfin, E. A. (2019). International Journal of Scientific Research and Reviews Determinants of Net Interest Margin in Selected Commercial Banks in Ethiopia. Enyew Alemaw Mesfin et Al, IJSRR, 2019(1), 1646-1655.

Suu, N. D., Luu, T. Q., Pho, K. H., \& McAleer, M. (2020). Net interest marginof commercial banks in Vietnam. Advances in Decision Sciences, 24(1), 1-27. https://doi.org/10.47654/v24y2020i1p1-27 